\title{
VARIATION IN BEHAVIOR OF BUFFY COAT CULTURES AMONG INDIVIDUALS OF DIFFERENT CONSTITUTION TYPES ${ }^{1}$
}

\author{
By GEORGE DRAPER, HELEN J. RAMSEY, AND C. W. DUPERTUIS \\ (From the Department of Medicine, College of Physicians and Surgeons, Columbia University, \\ and the Presbyterian Hospital, New York City)
}

(Received for publication January 6, 1944)

In view of well established gross constitutional similarities among subjects of a given disease, based on morphology and personality evaluation, the question arose whether analogous phenomena might likewise extend into the microscopic aspects of these subjects; whether the cells of all bodily tissues may show recognizable characteristics of appearance and reaction which stamp upon them an individuality comparable to that which marks the whole animal. The cells most readily available for such study and those which easily display observable qualities, because of their motility, are the leukocytes of the circulating blood. Consequently, an investigation of the buffy coat by tissue culture was undertaken.

Since the early cultures of human leukocytes by Awrorow and Timofejewskij in 1914 (1), the technic has been modified in various ways and has become a successful method for studying the behavior and developmental potentialities of the white blood cells. The chief concern of previous investigators has been with the sensitivity of fibroblasts and monocytes to their environment. Such studies have dealt with colonies of cells maintained in vitro for several days or weeks.

The present investigation is restricted to the first 24 to 30 hours of in vitro existence, during which time only slight changes in cell form have taken place. Freshly explanted cells have earlier been employed by Chambers and Grand $(2,3)$ in their studies of chemotactic reactions of leukocytes, and by Mallery and McCutcheon (4) who showed that the activity of freshly drawn leukocytes varies with the state of health of the patient from which they are taken. In the case of patients acutely ill with certain infectious diseases, cell motility is decreased. Lewis $(5,6)$ has described the locomotion of both neutrophilic leuko-

\footnotetext{
1 Aided by a grant from the National Foundation for Infantile Paralysis, Inc., N.Y.C.
}

cytes and lymphocytes in culture media. Finally, Carrel (7) has shown that buffy coat cultures from the blood of certain animal species take on individual patterns in vitro ( 5 to 6 days). Repeated cultures from the blood of a given individual yield identical cell patterns. The work of the above mentioned investigators has in many cases touched upon the problem of specific and even individual differences, but no comparative study, using man as the subject, appears to have been undertaken by this method.

Our object in this research was to investigate the possible existence of constitutional characters in the form and conduct of cells from the blood of human beings who were subjects of acute anterior poliomyelitis. ${ }^{2}$ For controls, buffy coats from constitutionally stamped susceptibles to three other diseases, namely peptic ulcer, coronary occlusion, and gall bladder disease, were used. These particular groups were chosen because it had already been shown that they display the greatest gross constitutional differences. Preliminary observation demonstrated that the greatest contrast in cell culture characteristics obtains between cultures from subjects of poliomyelitis and of gall bladder disease. The other controls, those bearing peptic ulcer and coronary disease, were found to be disposed at intermediate points between these two extremes. Now if the hypothesis of constitutional susceptibility is correct, then the individual characteristics should be demonstrable at any time in the subject's life. However, the obvious temporary changes which the body undergoes in acute, especially febrile illness, may to some extent distort or obscure some of the permanent criteria of the individual's personal identity in health. For this reason, blood was taken from

2 Poliomyelitis cases were made available through the courtesy of Willard Parker, Orthopedic, and Ruptured and Crippled Hospitals and the Jersey City Medical Center. 
some patients in the acute phase of infantile paralysis and from others during later stages of recovery. Indeed some of them had had their acute illness five to thirty years before. The latter were chosen in order to secure blood whose numerical and differential white cell counts were normal in the ordinary sense. From these observations, we have gained the impression that the culture characters herein described do not represent changes caused by the presence of the disease itself, but like the gross factors also express an aspect of the individual's constitution.

\section{METHOD}

The general picture of leukocyte migration in a plasma clot medium, as has been repeatedly shown by previous investigators, is as follows: The cells from the explanted buffy coat, incubated at $37.5^{\circ} \mathrm{C}$, begin to migrate outward in a uniform corona almost immediately, so that within 1 or 2 hours a macroscopically noticeable areola is formed. Monocytic cells preponderate in the van. Neutrophil leukocytes appear somewhat later and move outward more slowly. They are therefore found in greatest numbers near the explant. In 24 hours the extent of the areola is no longer well defined; it has become diffuse and generally covers the greater part of the area available. By this time the neutrophil leukocytes have begun to degenerate and disappear as have also some of the lymphocytes. Mononuclear cells have begun to increase in number by division. Changes in size and staining properties make it impossible to distinguish between lymphocytes and monocytes in most cases (8).

In the present studies, the following procedure was used :

A 7 cc. sample of blood was drawn into a syringe containing $1.1 \mathrm{cc}$. heparin in 1:2000 dilution. Further anticoagulant measures included maintenance of materials at low temperature and the use of tubes previously treated with $\mathrm{NaOH}$ for collection of blood, and tubes lined with paraffin for plasma.

Blood was centrifuged at 3500 r.p.m. for 15 minutes and the supernatant plasma pipetted off. The buffy coat was removed and divided into fragments about 1 $\mathrm{mm}$. in diameter. Tissue culture preparations were made by the Maximov slide method; 12 explants were usually prepared from the buffy coat of each patient's blood. All operations were carried out under sterile precautions.

The preparations were incubated at $37.5^{\circ} \mathrm{C}$. and observed at appropriate intervals. Since we were concerned principally with cells in their initial aspect rather than with transformation forms, cultures were maintained only 30 to 48 hours after explanation. The advance of cells into the culture medium was recorded by measuring the average width of the areola (to the nearest $0.1 \mathrm{~mm}$.) at $31 / 2$ and 24 hours, respectively. Records were kept of the degree of activity evinced by the cells, and of the types of cells present; cells were typed according to form and motility, not by hematological groups. Whole cultures were fixed and stained with Delafield's hematoxylin and eosin or with toluidine blue and eosin during early hours of incubation and at approximately 24 hours of incubation. Differential counts of hematological cell types were made for the 24-hour cultures, fields being counted at all levels of the areola from explant to advancing edge, including approximately 1000 cells. Total numbers of cells present in the entire areola, type distribution, etc., were then calculated.

\section{PROCEDURE}

Three hundred and twenty-eight cases, selected solely on the basis of the disease from which they had suffered were studied. As the work progressed, it soon appeared that age and sex played a minimal rôle in the phenomenon of culture growth. For this reason, these two factors were disregarded in the calculations. Characteristics of areola formation, rate of increase in areola size, aspect of the advancing margin, and cell form are best defined in most cases during the period from 2 to 5 hours after explantation. Further information on activity, shapes, and disposition of the various cells can be obtained after 24 hours of incubation. The various observations were therefore made on all cultures at these two stages.

Cultures from subjects of the 4 different maladies have been found to vary in the following respects :

1. Areolar size. After $3 \frac{1}{2}$ hours' incubation the areola breadths were measured and the following results obtained (Table I) :

TABLE I

Range, mean, and standard deviation of areola sizes after $3 \frac{1}{2}$ hours' incubation

\begin{tabular}{l|c|c|c|c}
\hline \hline & $\begin{array}{c}\text { No. } \\
\text { cases }\end{array}$ & Range & $\begin{array}{c}\text { Mean and } \\
\text { P.E. }\end{array}$ & S.D. \\
\hline Poliomyelitis & 28 & 0.4 to $1.3 \mathrm{~mm}$. & $0.79 \pm 0.04$ & 0.23 \\
Peptic ulcer & 35 & 0.5 to $1.5 \mathrm{~mm}$. & $\mathbf{0 . 8 6} \pm 0.03$ & $\mathbf{0 . 2 5}$ \\
Coronary disease & 20 & 0.9 to $1.8 \mathrm{~mm}$. & $1.19 \pm 0.03$ & 0.22 \\
Gall bladder disease & 48 & 0.5 to $1.7 \mathrm{~mm}$. & $1.19 \pm 0.02$ & 0.26 \\
\hline
\end{tabular}

From the above table, it appears that the areolas at $3 \frac{1}{2}$ hours of poliomyelitis and ulcer patients average smaller than those from coronary disease and gall bladder disease. The averages for the former 2 groups are approximately $0.8 \mathrm{~mm}$. and for the latter groups, $1.2 \mathrm{~mm}$.

That the differences between mean values are 
statistically significant and not due to sampling errors is indicated in Table II where the XPEs ${ }^{8}$ of these compared groups are for the most part above the significant level of 3 .

TABLE II

Differences of means and XPEs for intergroup comparisons of areola size, after $3 \frac{1}{2}$ hours' incubation

Poliomyelitis/Ulcer Difference and PE $0.07 \pm 0.05$

Poliomyelitis/Coronary

Poliomyelitis/Gall bladder

Ulcer/Coronary

Ulcer/Gall bladder

Coronary/Gall bladder

$0.40 \pm 0.05$

$0.40 \pm 0.045$

$0.33 \pm 0.042$

$0.33 \pm 0.036$

0

\section{XPE}

1.40

8.00

8.89

7.85

9.17

0

The same relative degree of difference in areola size was also evident in the cultures after 24 hours of incubation. Table III sets forth the values obtained for the 4 disease groups.

TABLE III

Range, mean, and standard deviation of areola sizes after 24 hours' incubation

\begin{tabular}{l|c|c|c|c}
\hline \hline & No. & Range & $\begin{array}{c}\text { Mean and } \\
\text { P.E. }\end{array}$ & S.D. \\
\hline Poliomyelitis & 25 & 1.0 to 6.0 & $3.13 \pm 0.14$ & 1.08 \\
Ulcer & 25 & 1.2 to 5.2 & $3.24 \pm 0.12$ & 0.91 \\
Coronary disease & 25 & 1.2 to 6.2 & $3.77 \pm 0.13$ & 0.99 \\
Gall bladder disease & 25 & 2.2 to 5.8 & $3.87 \pm 0.11$ & 0.81 \\
\hline
\end{tabular}

Table IV presents the differences of means of areola sizes after 24 hours' incubation. The mean values of the first two groups (poliomyelitis and ulcer) are again shown to be significantly smaller than those for the last two groups (coronary disease and gall bladder disease); this fact is indicated by the XPE values which are 3 or above in most instances.

TABLE IV

Differences of means and XPEs for intergroup comparisons of areola size, after 24 hours' incubation

Difference and P.E.

XPE

Poliomyelitis/Ulcer

$0.11 \pm 0.18$

$0.64 \pm 0.19$

$0.74 \pm 0.18$

$0.53 \pm 0.18$

$0.63 \pm 0.16$

$0.10 \pm 0.17$

0.61

3.37

4.11

2.94

Ulcer/Coronary

Ulcer/Gall bladder

Coronary/Gall bladder

3.94

The XPE is the difference between the means divided by the probable error of the difference. An XPE of 3 or more is considered to be statistically significant, for such a difference could only occur as a result of a sampling error in 4 cases out of 100 . The larger the XPE, the amaller the possibility that such a difference could have arisen as a result of chance sampling. Thus, an XPE of 4 signifies that such a difference between the means could only occur as a result of chance sampling in 7 cases out of 1000 trials.
In a general way, the size of the areola at the $31 / 2$-hour and 24-hour incubation periods enables us to identify the culture as belonging either to the poliomyelitis-ulcer groups, or to the coronary-gall bladder disease groups. Since areola size seems only able to discriminate between two main pairs, further observational detail is required to differentiate more precisely the four original groups. It should be added at this point that especially characteristic of cultures from poliomyelitis susceptibles is the frequent presence at the edge of the explant of narrow areas of clumped dead cells and cellular debris. These areas we have called "collars." In Tables VA, VB, and VC further detailed observational (non-measurable) criteria concerning areola and cells are given.

This table of detailed observational criteria was based on the observations made on 328 cases representing the 4 disease groups. It was found, for example, that most of the poliomyelitis areolas were narrow while those of the gall bladder patients were wide. The ulcer and coronary cases usually fell in between these two extremes with the former group almost invariably possessing a slightly thinner areola than the latter. Similarly it was found that the cells from poliomyelitis patients were generally active while those from gall bladder patients were very quiet. Again, the peptic ulcer and coronary cases showed a less extreme picture.

The items in this table, then, represent the most frequently occurring or "typical" patterns. These criteria have been accepted as more or less standard for the four disease groups. When the table of criteria was finally established, each one of 290 cases was graded on a seven-point scale of agreement or lack of agreement with the standards. Thus, we desired to know how many of our poliomyelitis cultures, for example, exhibited all or only a few of the typical characteristics for that disease group. A rating of 7 (excellent) signified that the culture complied with the standard in all respects ( 8 or 9 items), the areola was within the proper size range, the cells displayed the prescribed amount and variety of activity, and all other characterizing points were fulfilled. A rating of 5 (good) was given to those cultures which complied satisfactorily with the standard in most respects (6 items), that is, still easily recognizable as matching its particular group pattern. 
Cultures given a rating of 3 (fair) lacked many of the typical characteristics and were not easily recognizable as belonging to the proper pattern. Cultures classed 1 (unsatisfactory) were lacking in all but one or two items of the criteria for the specific disease group. The criteria used were 9 in number, 8 observational criteria and areola size.

In Table VII it is shown that 24 out of 84 poliomyelitis cultures possessed 8 or 9 criteria which have been judged typical for that disease group. Also, 34 out of 90 peptic ulcer cultures exhibited 8 or 9 criteria typical of that group. On the other hand, only 11 out of 47 coronary disease cultures and 10 out of 69 gall bladder disease cultures were rated 7 (excellent) on agreement between their observed criteria and those judged typical for these disease groups. Table VII also indicates that 69.0 per cent of the poliomyelitis cases conformed well (were rated 5 to 7 ) to the

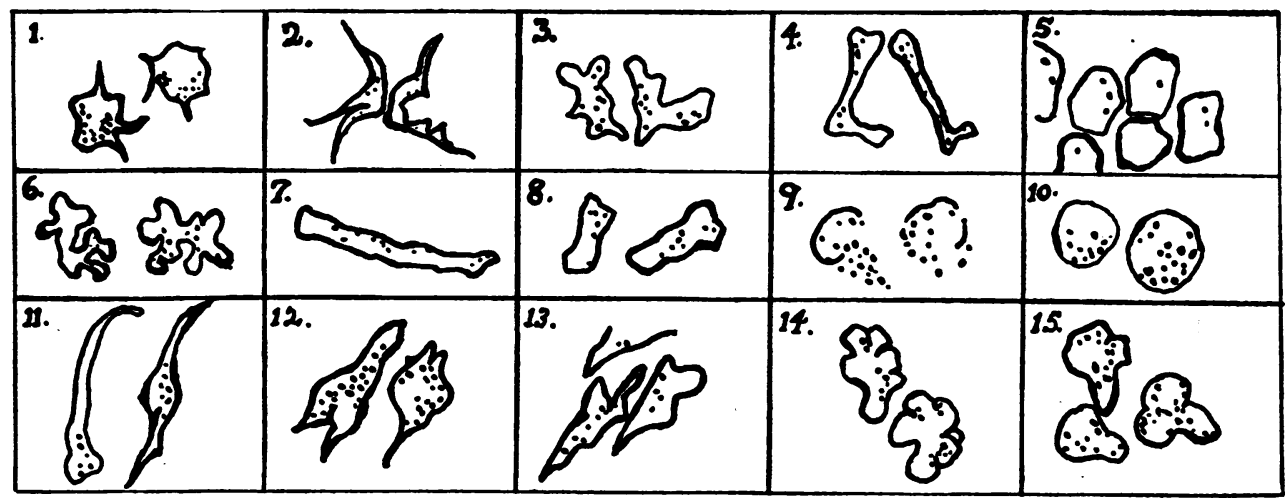

TABLE VA

\section{Semi-diagramatic appearance of different cell types}

1. Small, generally circular, with short, delicate spicules.

2. Irregularly branching form.

3. Leaf-like, rounded pseudopods.

4. Long, narrow, boot-like.

5. Square or polygonal; arranged like tiles.

6. Grotesque, "animal forms," angulated bodies, short, oval, and pointed pseudopodia.

7. Long; square-ended, rod-like forms.

8. Short, broad rods.

9. Ruptured polynuclears (ghosts).

10. Circular, inactive cells.

11. Long, club-shaped, or spindle-shaped cells.

12. Elliptical cells with one or two pointed pseudopods.

13. Medium-narrow, pointed cells, of ten lying in streaks.

14. Nobby, somewhat circular cells with small, blunt pseudopodia.

15. Pear-shaped cells with large, blunt, or broad-pointed pseudopodia.

\section{TABLE VB}

Preponderant cell forms

At 31 hours

Poliomyelitis $1,3,10,11,15$

Ulcer

Coronary

Gall bladder
$1,3,6,12,15$

1,3 , occasionally 5 , 4,14

$1,5,8$, occasionally 14,15

\section{At 24 hours}

$2,7,8,9,11$

3 , occasionally 5,6

$12,13,9,10$

3,4 , occasionally 6 , 9,10

same, with addition of 9

TABLE VC

Detailed observational criteria

\begin{tabular}{|c|c|c|c|c|c|c|c|c|}
\hline \multicolumn{2}{|c|}{$\begin{array}{c}\text { Areola } \\
\text { thickness }\end{array}$} & $\begin{array}{l}\text { Areola } \\
\text { margin }\end{array}$ & Collars & Clumping & $\begin{array}{l}\text { Cell con- } \\
\text { centration }\end{array}$ & $\begin{array}{l}\text { Degree of } \\
\text { motility }\end{array}$ & Pseudopodia & Cell shape \\
\hline \multicolumn{2}{|c|}{ Poliomyelitis: Narrow } & $\begin{array}{l}\text { Very } \\
\text { irregular }\end{array}$ & Numerous & Rare & $\begin{array}{l}\text { Light and } \\
\text { scattered }\end{array}$ & Active & $\begin{array}{l}\text { Short and } \\
\text { bluntish }\end{array}$ & $\begin{array}{l}\text { Rod shapes and } \\
\text { linear forms }\end{array}$ \\
\hline Ulcer: & Medium & $\begin{array}{l}\text { Fairly } \\
\text { regular }\end{array}$ & Rare & Rare & $\begin{array}{l}\text { More } \\
\text { dense }\end{array}$ & $\begin{array}{l}\text { Less } \\
\text { active }\end{array}$ & $\begin{array}{l}\text { One or two } \\
\text { pointed, } \\
\text { medium long }\end{array}$ & $\begin{array}{l}\text { Pear shaped } \\
\text { pointed } \\
\text { pseudopods }\end{array}$ \\
\hline Coronary: & Slightly wide & Regular & None & Medium & $\begin{array}{l}\text { Still more } \\
\text { dense }\end{array}$ & $\begin{array}{l}\text { Still less } \\
\text { active }\end{array}$ & $\begin{array}{l}\text { Many small } \\
\text { nodular, or } \\
\text { rounded }\end{array}$ & Ovoid rounded \\
\hline Gall bladde & Wide & $\begin{array}{l}\text { Very } \\
\text { regular }\end{array}$ & None & $\begin{array}{l}\text { Almost } \\
\text { constant }\end{array}$ & $\begin{array}{l}\text { Very } \\
\text { dense }\end{array}$ & $\begin{array}{l}\text { Very } \\
\text { quiet }\end{array}$ & $\begin{array}{l}\text { Few-broad } \\
\text { and normal }\end{array}$ & $\begin{array}{l}\text { Rounded, } \\
\text { flattish }\end{array}$ \\
\hline
\end{tabular}


TABLE VI

Rating scale in terms of typical criteria

A culture possessing 8 to 9 typical criteria is rated 7 (excellent) on agreement

A culture possessing

A culture possessing

A culture possessing

A culture possessing

A culture possessing

7 typical criteria is rated 6 (very good) on agreement

6 typical criteria is rated 5 (good) on agreement

5 typical criteria is rated 4 (fairly good) on agreement

4 typical criteria is rated 3 (fair) on agreement

3 typical criteria is rated 2 (poor) on agreement

A culture possessing 1 to 2 typical criteria is rated 1 (unsatisfactory) on agreement

TABLE VII

Agreement between individual cultures and the standards for their respective groups for 290 cases $A$ 7-point scale is used in which a rating of 7 is excellent, 5 good, 3 fair, and 1 poor

\begin{tabular}{|c|c|c|c|c|c|c|c|c|}
\hline \multirow[b]{2}{*}{$\begin{array}{c}\text { culture rating } \\
7 \\
6 \\
5 \\
4 \\
3 \\
2 \\
1\end{array}$} & \multicolumn{2}{|c|}{ Poliomyelitis } & \multicolumn{2}{|c|}{ Peptic ulcer } & \multicolumn{2}{|c|}{ Coronary disease } & \multicolumn{2}{|c|}{ Gall bladder disease } \\
\hline & $\begin{array}{c}\text { number } \\
24 \\
17 \\
17 \\
15 \\
8 \\
2 \\
1\end{array}$ & $\begin{array}{r}\text { per cent } \\
28.6 \\
20.2 \\
20.2 \\
17.9 \\
9.5 \\
2.4 \\
1.2\end{array}$ & $\begin{array}{c}\text { number } \\
34 \\
26 \\
18 \\
8 \\
3 \\
1 \\
0\end{array}$ & $\begin{array}{r}\text { per cent } \\
37.8 \\
28.9 \\
20.0 \\
8.9 \\
3.3 \\
1.1 \\
0.0\end{array}$ & $\begin{array}{c}\text { number } \\
11 \\
23 \\
9 \\
4 \\
0 \\
0 \\
0\end{array}$ & $\begin{array}{c}\text { per cent } \\
23.4 \\
48.9 \\
19.2 \\
8.5 \\
0.0 \\
0.0 \\
0.0\end{array}$ & $\begin{array}{c}\text { number } \\
10 \\
20 \\
19 \\
11 \\
6 \\
2 \\
1\end{array}$ & $\begin{array}{r}\text { per cent } \\
14.5 \\
29.0 \\
27.6 \\
15.9 \\
8.7 \\
2.9 \\
1.4\end{array}$ \\
\hline Total & 84 & 100.0 & 90 & 100.0 & 47 & 100.0 & 69 & 100.0 \\
\hline $\begin{array}{l}5-7 \\
1-4\end{array}$ & $\begin{array}{l}58 \\
26\end{array}$ & $\begin{array}{l}69.0 \\
31.0\end{array}$ & $\begin{array}{l}78 \\
12\end{array}$ & $\begin{array}{l}86.7 \\
13.3\end{array}$ & $\begin{array}{r}43 \\
4\end{array}$ & $\begin{array}{r}91.5 \\
8.5\end{array}$ & $\begin{array}{l}49 \\
20\end{array}$ & $\begin{array}{l}71.1 \\
28.9\end{array}$ \\
\hline
\end{tabular}

standards for that disease group and were therefore judged to be typical poliomyelitis cultures. Similarly, 86.7 per cent of the peptic ulcer cases, 92.5 per cent of the coronary cases, and 71.1 per cent of the gall bladder cases were endowed with a sufficient number of criteria to be representative of their respective disease groups.

At this stage, it must be pointed out that if the poliomyelitis cultures, for example, were rated on the criteria for any of the other 3 disease groups, the agreement would be of a very low order. It is obvious, we believe, that the agreement ratings are for the most part mutually exclusive. That is, if a gall bladder culture is observed to possess a large percentage of the 9 criteria which we have judged to be typical for that disease group it is impossible for it to possess at the same time a large percentage of the criteria which are typical of any of the other 3 disease groups. There have been some instances in which gall bladder cultures, for example, possessed criteria which were more in agreement with those typical of the peptic ulcer or poliomyelitis groups and therefore could not be classified as typical gall bladder cultures. These overlaps, however, were found to be relatively rare. As a result of the above reasoning, we have found it possible to diagnose correctly slightly better than 70 per cent of specimens from unknown sources within the 4 groups.

\section{DIFFERENTIAL CELL COUNTS}

The approximate total number of cells per areola at $3 \frac{1}{2}$ hours of incubation was as follows: Poliomyelitis 6000 cells, peptic ulcer 17,000 cells,

\section{PLATE I}

Fig. 1. Areola About Explanted Fragment of Buffy Coat from Blood of Poliomyelitis Patient, $31 / 2$ Hours in vitro. $\times 25$. Compare with Figures 2, 3 , and 4.

Fig. 2. Arbola About Explanted Fragment of Buffy Cont from Blood of Peptic Ulcer Patient, $3 \mathrm{~T} / 2$ Hours in vitro. $\times 25$.

Fig. 3. Areola About Explanted Fragment of
Buffy Cont From Blood of Coronary Patient, 3 $3 \frac{1}{2}$ Hours in vitro. $\times 25$.

Fig. 4. Areola About Explanted Fragment of Buffy Coat From Blood of Gall Bladder Patient, $3 \mathrm{~T} / 2$ Hours in vitro. $\times 25$.

Fig. 5. Cells in Culture from Blood of PolioMYelitis Patient, 24 Hours in vitro. $\times 360$. Note elongated cells. 

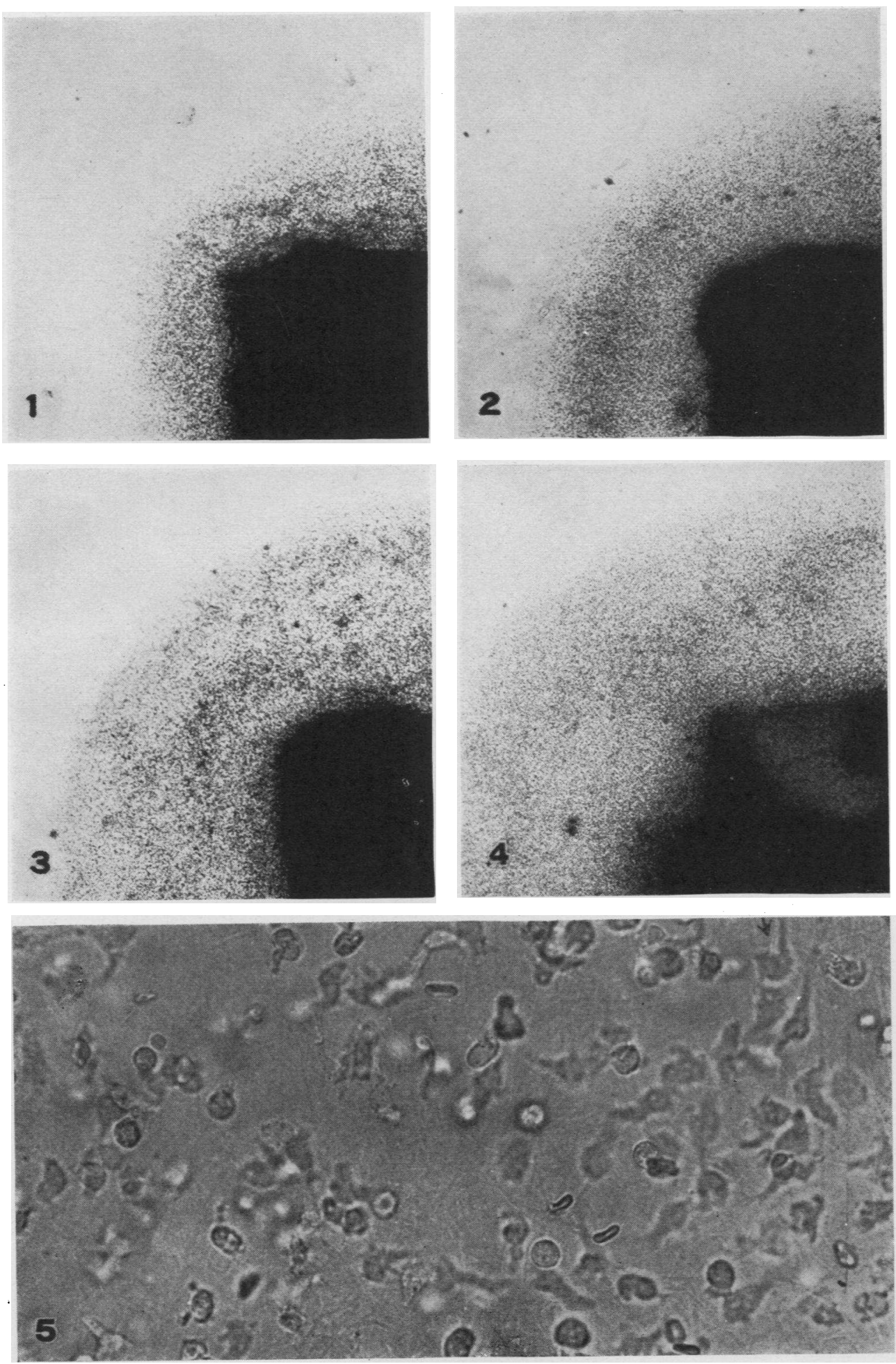

PLATE I 
TABLE VIII

Differential counts of areolar cells in 4-hour cultures

\begin{tabular}{|c|c|c|c|c|c|c|c|c|}
\hline & \multicolumn{2}{|c|}{ Poliomyelitis } & \multicolumn{2}{|c|}{ Peptic ulcer } & \multicolumn{2}{|c|}{ Coronary disease } & \multicolumn{2}{|c|}{ Gall bladder disease } \\
\hline & number & percent & number & percent & number & percent & number & percent \\
\hline Neutrophils & 3,300 & 55.0 & 9,740 & 57.3 & 16,550 & 59.1 & 21,760 & 64.0 \\
\hline Mononuclear cells & 2,700 & 45.0 & 6,920 & 40.7 & 11,450 & 40.9 & 12,240 & 36.0 \\
\hline Eosinophils & 0 & 0 & 190 & 1.1 & 0 & 0 & 0 & 0 \\
\hline Unidentified cells & 0 & 0 & 150 & 0.9 & 0 & 0 & 0 & 0 \\
\hline Total & 6,000 & 100.0 & 17,000 & 100.0 & 28,000 & 100.0 & 34,000 & 100.0 \\
\hline
\end{tabular}

coronary disease 28,000 cells, gall bladder disease 34,000 cells. Cell counts at the 24 -hour period still showed considerable variation among the disease groups. Approximations of total cellular content of the areolas at this stage were: poliomyelitis 53,000 cells, peptic ulcer 78,000 cells, coronary disease 91,000 cells, and gall bladder disease 121,000 cells.

It will be noticed that in the foregoing paragraphs attention has been directed only to the shapes and disposition of the leukocytes, without regard to their identity as neutrophils, monocytes, etc. By fixation and staining of whole cultures, interesting information may be brought to light concerning the proportional distribution of the hematological types.

Consequently, a set of 100 unselected cases, 25 patients from each of the 4 groups, has been drawn up in which differential counts of the hematological types of cells present in 4-hour and 24hour cultures were made on specified sectors of the areolas, approximately 1000 cells per areola being counted. ${ }^{4}$ At 24 hours it is impossible to distinguish between most monocytes and lympo-

* The number of cells was counted in each successive oil immersion field from the explant outward to the edge of the areola.

Total number of cells $=12.4(3 \mathrm{~A}+7 \mathrm{~B}+11 \mathrm{C}+15 \mathrm{D}+$ 19C etc.) in which $A=$ sum of 1 st 6 oil immersion fields

$\mathrm{B}=$ sum of 2 nd 6 oil immersion fields

$\mathrm{C}=$ sum of 3 rd 6 oil immersion fields etc. cytes since there are various changes in size and staining properties at this periol. The distinction on the basis of size is also founded on an arbitrary division. These two varieties have therefore been consolidated in the present report under the designation "mononuclear" cells. Most of the cells classed as unidentified are polynucleated forms, perhaps representing stages in cell multiplication. The differential counts are summarized in Tables VIII and IX.

It would appear that the differences in total and differential counts as shown in Tables VIII and IX may be definitely related to the different sizes and characters of the areolas as described above. It is also evident that the polynuclear neutrophils play the major part in these variations.

It is noteworthy that in the gall bladder cultures the absolute neutrophil count is 81,900 as against 12,150 for poliomyelitis; the respective mononuclear counts are 34,600 and 37,100 . It is therefore obvious that, at least in the 24-hour culture, the difference in total count is altogether due to a difference in absolute neutrophil count.

\section{DISCUSSION}

In attempting to interpret the meaning of the foregoing observations, it should be pointed out that many of the distinguishing characteristics noted in living cultures may be attributed simply to the numbers and relative proportions of the various cell types. But, in addition, there are

\section{PLATE II}

Fig. 6. Cells in Clilture from Blood of Poliomyelitis Patient, 24 Hours in vitro. $\times 480$. Compare with Figures 7, 8, and 9.

Fig. 7. Cells in Culture from Blood of Peptic Ulcer Patient, 24 Hours in vitro. $\times 480$.
Fig. 8. Cells in Culture from Blood of Coronary Patient, 24 Hours in vitro. $\times 380$.

Fig. 9. Cells in Cultere from Blood of Gali Bladder Patient, 24 Hours in vitro. $\times 480$. 

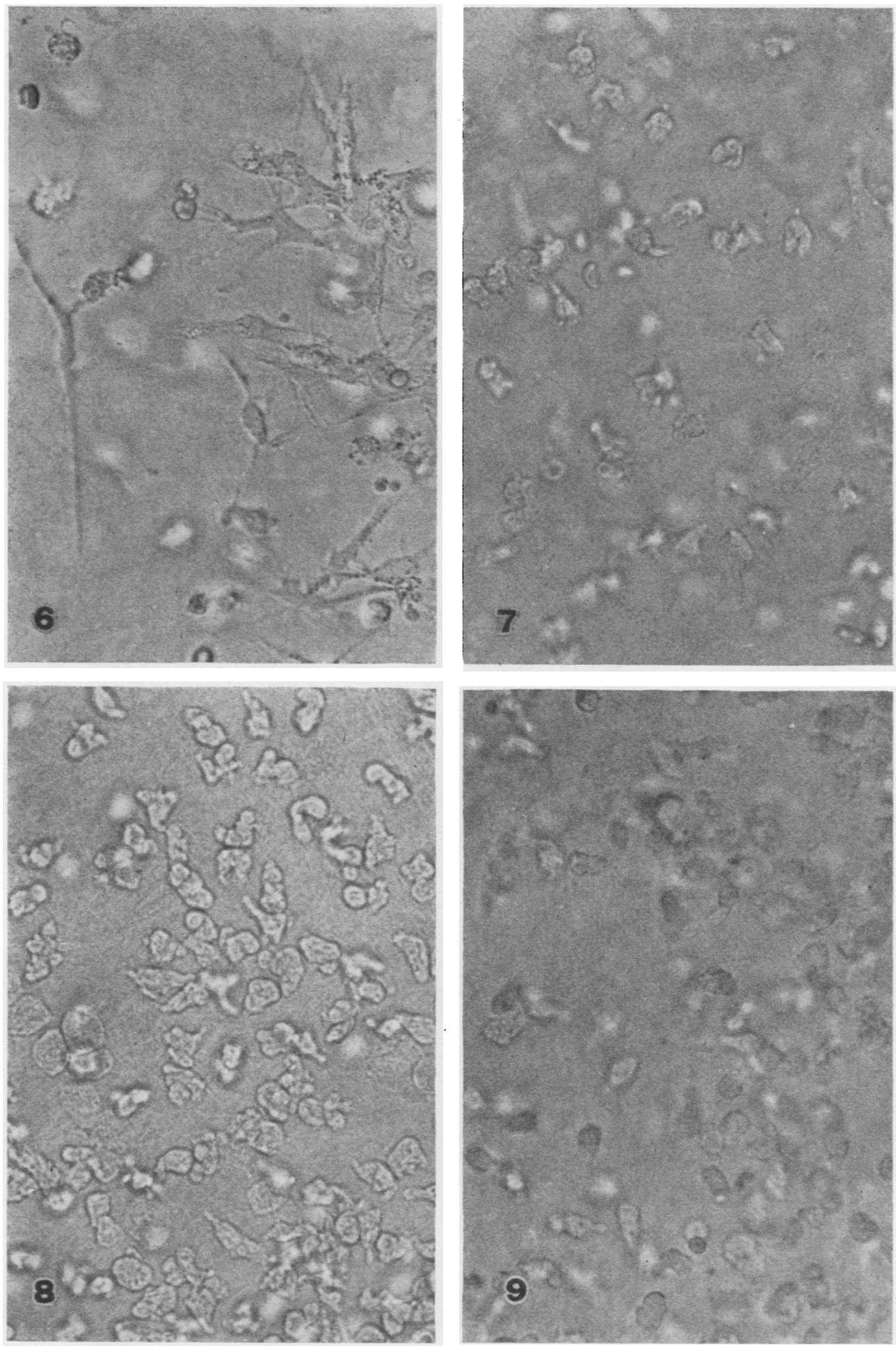

PLATE II 
TABLE IX

Differential counts of areolar cells in 24-hour cultures

\begin{tabular}{|c|c|c|c|c|c|c|c|c|}
\hline & \multicolumn{2}{|c|}{ Poliomyelitis } & \multicolumn{2}{|c|}{ Peptic ulcer } & \multicolumn{2}{|c|}{ Coronary disease } & \multicolumn{2}{|c|}{ Gall bladder disease } \\
\hline $\begin{array}{l}\text { Neutrophils } \\
\text { Mononuclear cells } \\
\text { Eosinophils } \\
\text { Unidentified cells }\end{array}$ & $\begin{array}{r}\text { number } \\
12,150 \\
37,100 \\
150 \\
3,600\end{array}$ & $\begin{array}{c}\text { per cent } \\
22.9 \\
70.0 \\
0.3 \\
6.8\end{array}$ & $\begin{array}{r}\text { number } \\
23,700 \\
50,300 \\
250 \\
3,750\end{array}$ & $\begin{array}{r}\text { per cent } \\
30.4 \\
64.5 \\
0.3 \\
4.8\end{array}$ & $\begin{array}{r}\text { number } \\
50,200 \\
35,400 \\
180 \\
5,220\end{array}$ & $\begin{array}{c}\text { per cent } \\
55.2 \\
38.9 \\
0.2 \\
5.7\end{array}$ & $\begin{array}{r}\text { number } \\
81,900 \\
34,600 \\
250 \\
4,250\end{array}$ & $\begin{array}{r}\text { per cent } \\
67.7 \\
28.6 \\
0.2 \\
3.5\end{array}$ \\
\hline Total & 53,000 & 100.0 & 78,000 & 100.0 & 91.000 & 100.0 & 121,000 & 100.0 \\
\hline
\end{tabular}

other qualities which do not, to our knowledge, depend upon discernible hematological differences, but presumably upon some factor or factors which independently influence individual cell behavior. These qualities are expressed in the plastic aspect and modes of cellular locomotion. The obvious differences in general appearance between cultured cells from poliomyelitis and gall bladder patients, for example, or between those with ulcer and those with coronary disease are not solely quantitative. We are convinced that these living leukocytes assume in one case noticeably different plastic appearances and movements from those in another. This phenomenon may express certain qualities of constitutional physiology and may be analogous to the individual differences so easily seen in any whole living animal.

The immediate reason for decrease and disappearance of polymorphonuclear cells at an earlier hour in certain cultures than in others may, at this point, only be conjectured. A difference in fragility of the cells, reflected in their resistance to the mechanical forces involved in centrifugation and handling may be a factor. It is typical of the poliomyelitis cultures to find collars of disintegrated cells at the edge of the explant. But there is no doubt that variable energy in locomotion may be another. Differences in mononuclear cells in regard to aspect, mobility, and cell multiplication can undoubtedly be demonstrated. But it must not be overlooked that chemical and physical variation in the plasma may be partially or wholly responsible.

Much experimentation already reported in the literature has seemed to indicate that it is the medium in which the cells are maintained which primarily determines culture pattern $(7,11,12)$. In the case of leukocytes cultivated in auto- genous as well as homogenous plasma (plus 9day chick extract), it is very likely that there are slight differences in chemical content of the plasma of the various individuals studied, which in some degree influence the behavior of the cells. In this connection, Baker reports that various proteolytic digestion products have different effects on the morphological appearance of the monocytes (13). However, the limited investigation of the media which we have made (namely crossing plasma and cells) points toward the conclusion that concerning in vitro behavior the plasma base does influence the pattern to some extent, but that this is a factor of less importance than normal variations among the cells themselves. It is impossible at this time to mark out clearly the interrelation of these two factors, but the question is of minor importance to the issue at hand. Since both plasma and cells in any of our preparations originate from the whole blood sample, the eventual manifestation of variation in terms of cell behavior may be regarded as a valid constitutional criterion regardless of the relative weight of factors determining that behavior. The most striking result of these studies is the vast difference displayed by comparing the patterns of buffy coat cultures from subjects of poliomyelitis and those of gall bladder disease. Less emphatic differential criteria are also discoverable in the samples from ulcer and coronary disease. But because these groups occupy intermediary positions the differences between the patterns of adjacent groups do not achieve such an extreme order of magnitude as in the first mentioned comparison.

The studies of gross constitution which have been based upon the observation and record of the four panels of personality (morphology, physiology, psychology, and immunity) have shown 
that individual human types correlate with specific disease potentialities. From the study of the buffy coat cultures, similar correlations likewise appear. Thus, for example, in 217 of the 290 cases it has been possible to obtain evaluations for gross constitutional characteristics of the individual as well as culture ratings. These gross ratings are based on anthropomorphic, physiological, and psychological criteria recognized for subjects of each disease group. These standards have been described elsewhere $(9,10)$. A tabulation of these two sets of data follows (Table X).

Each of the two methods (gross or microscopic) shows an emphatic tendency to agree with the accepted standard for the method. The significance of the information derived from these two sources is not clear. But there is no question that the knowledge contributed by each points to the important conclusion that the personal identity of each individual is complete. It should be emphasized that by both methods some overlappings of types are found, but these are not sufficient to blur out the fundamentally basic type differences. In view of these observations, consequently, it would seem profitable to pursue further the cellular approach to constitutional research, and to include the cells of other body tissues in similar studies.

\section{SUMMARY}

1. Application of the technic of tissue culture to the problem of evaluating individual human constitution has demonstrated that each cell may display characters of aspect and behavior quite as specific as those which stamp the individual as a whole. Leukocytes from individuals of four disease groups-poliomyelitis, peptic ulcer, coronary disease, and gall bladder disease-were studied.

2. After $3 \frac{1}{2}$ hours, in vitro differences in areola size, form, and cellular content were demonstrated in the buffy coat cultures from poliomyelitis, peptic ulcer, coronary disease, and gall bladder disease.

3. Individual cultures were rated on a 7-point scale according to the degree to which they complied with standards for each of the four disease groups. Ratings of 5 (good) or above were assigned to 69.0 per cent of the poliomyelitis cases, to 86.7 per cent of the peptic ulcer cases, to 92.5 per cent of the coronary cases, and to 71.1 per cent of the gall bladder cases.

4. In 100 cases, differential counts were made on the areolar cells after 4 and 24 hours' incubation. Slight variation among the groups at 4 hours was exaggerated after 24 hours to display positive differences. In cultures from poliomyelitis patients, at one extreme, there was a preponderance of mononuclear cells and a scarcity of neutrophils, while in cultures from gall bladder patients, at the other extreme, were found a high neutrophil count and relatively few mononuclear cells. Cultures from the other two disease groups fell between these two extremes.

TABLE $X$

Agreement of culture ratings and gross constitutional ratings with standards for their respective groups for 217 cases A 7-point scale is used in which a rating of 7 is excellent, 5 good, 3 fair, and 1 poor

\begin{tabular}{|c|c|c|c|c|c|c|c|c|c|c|c|c|c|c|c|c|}
\hline \multirow{3}{*}{$\begin{array}{l}\text { Culture } \\
\text { rating }\end{array}$} & \multicolumn{4}{|c|}{ Poliomyelitis } & \multicolumn{4}{|c|}{ Peptic ulcer } & \multicolumn{4}{|c|}{ Coronary disease } & \multicolumn{4}{|c|}{ Gall bladder disease } \\
\hline & \multicolumn{2}{|c|}{ Culture } & \multicolumn{2}{|c|}{ Gross } & \multicolumn{2}{|c|}{ Culture } & \multicolumn{2}{|c|}{ Gross } & \multicolumn{2}{|c|}{ Culture } & \multicolumn{2}{|c|}{ Gross } & \multicolumn{2}{|c|}{ Culture } & \multicolumn{2}{|c|}{ Gross } \\
\hline & num- & $\begin{array}{l}\text { per } \\
\text { cent }\end{array}$ & $\underset{\text { ber }}{\text { num- }}$ & $\begin{array}{l}\text { per } \\
\text { cent }\end{array}$ & $\underset{\text { ber }}{\text { num- }}$ & $\begin{array}{l}\text { per } \\
\text { cent }\end{array}$ & $\underset{\text { ber }}{\text { num- }}$ & $\begin{array}{l}\text { per } \\
\text { cent }\end{array}$ & num- & $\begin{array}{l}\text { per } \\
\text { cent }\end{array}$ & $\underset{\text { ber }}{\text { num- }}$ & $\begin{array}{l}\text { per } \\
\text { cent }\end{array}$ & num- & $\begin{array}{l}\text { per } \\
\text { cent }\end{array}$ & $\begin{array}{c}\text { num- } \\
\text { ber }\end{array}$ & $\begin{array}{l}\text { per } \\
\text { cent }\end{array}$ \\
\hline $\begin{array}{l}7 \\
6 \\
5 \\
4 \\
3 \\
2 \\
1\end{array}$ & $\begin{array}{r}19 \\
13 \\
12 \\
13 \\
7 \\
1 \\
0\end{array}$ & $\begin{array}{r}29.2 \\
20.0 \\
18.5 \\
20.0 \\
10.8 \\
1.5 \\
0.0\end{array}$ & $\begin{array}{r}10 \\
19 \\
30 \\
5 \\
0 \\
0 \\
1\end{array}$ & $\begin{array}{r}15.4 \\
29.2 \\
46.2 \\
7.7 \\
0.0 \\
0.0 \\
1.5\end{array}$ & $\begin{array}{r}23 \\
19 \\
12 \\
5 \\
1 \\
1 \\
0\end{array}$ & $\begin{array}{r}37.7 \\
31.1 \\
19.7 \\
8.3 \\
1.6 \\
1.6 \\
0.0\end{array}$ & $\begin{array}{r}18 \\
24 \\
12 \\
4 \\
1 \\
2 \\
0\end{array}$ & $\begin{array}{r}29.5 \\
39.3 \\
19.7 \\
6.6 \\
1.6 \\
3.3 \\
0.0\end{array}$ & $\begin{array}{r}11 \\
18 \\
8 \\
3 \\
0 \\
0 \\
0\end{array}$ & $\begin{array}{r}27.5 \\
45.0 \\
20.0 \\
7.5 \\
0.0 \\
0.0 \\
0.0\end{array}$ & $\begin{array}{r}5 \\
13 \\
16 \\
2 \\
4 \\
0 \\
0\end{array}$ & $\begin{array}{r}12.5 \\
32.5 \\
40.0 \\
5.0 \\
10.0 \\
0.0 \\
0.0\end{array}$ & $\begin{array}{r}8 \\
14 \\
12 \\
7 \\
5 \\
1 \\
1\end{array}$ & $\begin{array}{r}16.7 \\
29.2 \\
25.0 \\
14.6 \\
10.4 \\
2.1 \\
2.1\end{array}$ & $\begin{array}{r}11 \\
7 \\
8 \\
12 \\
6 \\
2 \\
2\end{array}$ & $\begin{array}{r}22.9 \\
14.6 \\
16.7 \\
25.0 \\
12.5 \\
4.2 \\
4.2\end{array}$ \\
\hline Total & 65 & 100.0 & 65 & 100.0 & 61 & 100.0 & 61 & 100.0 & 40 & 100.0 & 40 & 100.0 & 48 & 100.1 & 48 & 100.1 \\
\hline $\begin{array}{l}5 \text { to } 7 \\
1 \text { to } 4\end{array}$ & $\begin{array}{l}44 \\
21\end{array}$ & $\begin{array}{l}67.7 \\
32.3\end{array}$ & $\begin{array}{r}59 \\
6\end{array}$ & $\begin{array}{r}90.8 \\
9.2\end{array}$ & $\begin{array}{r}54 \\
7\end{array}$ & $\begin{array}{l}88.5 \\
11.5\end{array}$ & $\begin{array}{r}54 \\
7\end{array}$ & $\begin{array}{l}88.5 \\
11.5\end{array}$ & $\begin{array}{r}37 \\
3\end{array}$ & $\begin{array}{r}92.5 \\
7.5\end{array}$ & $\begin{array}{r}34 \\
6\end{array}$ & $\begin{array}{l}85.0 \\
15.0\end{array}$ & $\begin{array}{l}34 \\
14\end{array}$ & $\begin{array}{l}70.9 \\
29.2\end{array}$ & $\begin{array}{l}26 \\
22\end{array}$ & $\begin{array}{l}54.2 \\
45.9\end{array}$ \\
\hline
\end{tabular}


5. It is our opinion that the results warrant further study of the subject.

At this point, we take pleasure in extending our thanks and appreciation to Dr. A. P. Stout, Director of the Surgical Pathology Laboratory of the College of Physicians and Surgeons, and to his associate, Dr. M. R. Murray, for their cooperation in starting this research and working out adaptations of tissue culture technic for our special study. To Mrs. Irene Pogogeff who set up many of the early cultures, we are likewise indebted. It should be mentioned that the original grant of funds which started this work was given as a memorial to their daughter by Mr. and Mrs. E. H. Robins of Washington, D. C.

\section{BIBLIOGRAPHY}

1. Awrorow, P. P., and Timofejewskij, A. D., Kultivierungsversuche von leukämishem Blute. Virchows Arch., 1914, 216, 184.

2. Chambers, R., and Grand, C. G., Chemotactic reaction of leucocytes to foreign substances in tissue culture. J. Cell. and Comp. Physiol., 1936, 8, 1.

3. Grand, C. G., and Chambers, R., The chemotactic reaction of leucocytes to irritated tissues. J. Cell. and Comp. Physiol., 1936, 9, 165.

4. Mallery, O. T., Jr., and McCutcheon, M., Motility and chemotaxis of leukocytes in health and disease. Am J. M. Sc., 1940, 200, 394.

5. Lewis, W. H., Migration of neutrophilic leucocytes. Arch. f. exper. Zellforsch., 1927, 4, 442.

6. Lewis, W. H., Locomotion of lymphocytes. Bull. Johns Hopkins Hosp., 1931, 49, 29.

7. Carrel, A. Monocytes as indicator of certain states of blood serum. Science, 1934, 80, 565.

8. Bloom, W., Tissue cultures of blood and bloodforming tissues. In Handbook of Hematology, H. Downey, ed., Vol. II, Paul B. Hoeber, Inc., New York, 1938. Pages 1469-1585.

9. Draper, G., Dupertuis, C. W., and Caughey, J. L., Jr., Human Constitution in Clinical Medicine. Paul B. Hoeber, Inc., New York, 1944. Chapter XII.

10. Ibid.

11. Carrel, A., and Ebeling, A. H., Indice de croissance du sérum sanguin. Compt. Rend. Soc. de Biol., 1924, 90, 170.

12. Swift, H. F., Moen, J. K., and Vaubel, E., Varying influence of tuberculous rabbit plasma on growth of fibroblasts in vitro. J. Exper. Med., 1934, 60, 149.

13. Baker, L. E., The effect of proteolytic digestion products on multiplication and morphological appearance of monocytes. J. Exper. Med., 1933, 57, 689. 